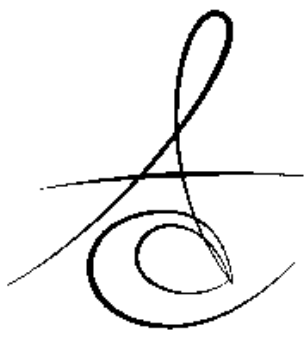

\title{
THE STRESS DISTRIBUTION EVALUATION OF TWO DIFFERENT POST TYPES WHICH USED IN ANTERIOR TEETH WITH COMPLICATED CROWN-ROOT FRACTURE: A FINITE ELEMENT ANALYSIS METHOD
}

\section{KOMPLİKE KRON-KÖK KIRIĞI OLUŞMUŞ ÖN GRUP DİŞLERDE KULLANILAN İKİ FARKLI POST TİPİNİN STRES DAĞILIMININ DEĞERLENDIİRİLMESİ: SONLU ELEMENT ANALİZ YÖNTEMİ}

\author{
Dr. Abdullah Emre KARAALí \\ Dr.öğr.Üyesi Mehmet Sinan DOĞAN** \\ Dr. Ayşe GÜNAY***
}

Makale Kodu/Article code: 3481

Makale Gönderilme tarihi: 23.08.2017

Kabul Tarihi: 22.02.2018

\section{ABSTRACT}

Aim: The aim of this study was to compare the stress distribution under artificial forces that simulate the biting forces of the two different post types used in maxillary anterior teeth that had complicated crownroot fractures and to determine the region where the stress occurred. For this purpose, a finite element analysis method was used.

Material and method: In the study, Glass fiber post (Group I) and carbon fiber post (Group II) were used to model tooth with complicated crown-root fracture, which would be horizontal in the cervical region of the fracture line. In the model, fractured teeth fragment (coronal and root fragments) were reattachment to by post. The force of $100 \mathrm{~N}$ was applied to the incisal of the teeth at $90^{\circ}$ angles to the groups (longitudinal axis). Finite element analysis method was used to evaluate stress resulting from force and to obtain a three-dimensional model. Analyzes were done with the ANSYS program (ANSYSRel.6.0, ANSYS Inc., Houston, TX, USA).

Results: As the results of the analysis, the resistance of glass fiber post against the forces was higher than the carbon fiber post. The stresses were concentrated mostly at the palatinal regions in group I and II.

Conclusion: The rehabilitation of esthetic and functional for anterior group teeth with complicated crown-root fractures was favorable glass fiber post than carbon fiber post.

Keywords: Dental trauma, crown-root fracture, glass fiber post, carbon fiber post, FEM

\section{öz}

Amaç: Bu çalışmanın amacı, komplike kron-kök kırığı gerçekleşen ön grup dişlerde kullanılan iki farklı post tipinin ısırma kuvvetlerini taklit eden yapay kuvvetler altında stres dağılımının karşılaştırılması ve stresin oluştuğu bölgenin belirlenmesidir. $\mathrm{Bu}$ amaç doğrultusunda sonlu elemanlar analiz yöntemi kullanıldı.

Gereç ve Yöntem: Çalışmada kırık hattı dişin kole bölgesinde yatay olacak şekilde komplike kron-kök kırığı oluşturulan diş modeline cam fiber post (Grup I) ve karbon fiber post (Grup II) kullanıldı. Modeldeki kırık diş parçaları (kronal ve kök parçaları) post yardımıyla yeniden yapıştırıldı. Gruplara 100N kuvvet dişlerin insizal kenarına 90 derecelik açı ( dişin uzun aksına) ile uygulandı. Kuvvet sonucu oluşan stresi değerlendirmek ve üç boyutlu model elde etmek için sonlu elemanlar analiz yöntemi kullanıldı. Analizler ANSYS programı ile yapıldı.

Bulgular: Analiz sonuçlarına göre, cam fiber postun kuvvetlere karşı direnci karbon fiber posta göre daha yüksek bulundu. Ayrıca stresler çoğunlukla her iki grupta dişin palatinal bölgelerinde yoğunlaşmıştır.

Sonuç: Komplike kron- kök kırıklarına maruz kalan üst ön grup dişlerde estetik ve fonksiyonel iyileştirme sağlamak için karbon fiber posta göre cam fiber postun kullanımı daha uygun bulundu.

Anahtar Kelimeler: Dental travma, kron-kök kırığı, cam fiber post, karbon fiber post, FEM

\footnotetext{
${ }^{*}$ Special Dental Clinical, Hatay/TURKEY.

** Harran University, Faculty of Dentistry, Department of Pediatric Dentistry, Şanliurfa

*** Dicle University, Faculty of Dentistry, Department of Pediatric Dentistry, Diyarbakır
}

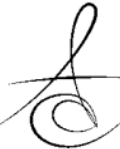


Atatürk Üniv. Diş Hek. Fak. Derg.

J Dent Fac Atatürk Uni

Cilt:28, Sayı:3, Yıl: 2018, Sayfa, 326-332
KARAALİ, DOĞAN, GÜNAY

\section{INTRODUCTION}

Dental trauma is most commonly seen among children and adolescent, and in maxillary central teeth. In teeth with complicated fractures, aesthetic and functional rehabilitation is very difficult and often requires a multidisciplinary approach. ${ }^{1}$

The crown-root fractures (CRF) occur when the direction of the trauma is horizontal. Crown fracture may reach to the inside of alveolar bone at palatal region obliquely. Mobility of the coronal part is significant for the clinical diagnosis. CRF may be difficult radiological diagnosis, if $X$-rays do not pass through the fracture line. Some difficulties may occur for the child, family and clinician while treating permanent teeth with CRF. There are several CRF treatments in anterior teeth. If the fracture line is above the alveolar bone, restorative treatment can be performed following extraction of the fractured part. However, if the fracture line is under the alveolar bone, gingivectomy or osteotomy procedures have to be performed before the restoration. If the fracture line is deeply under the alveolar bone and any restoration cannot be performed, both coronal and the root part can be extracted. However, if the clinician needs the root part strategically, orthodontic or surgical extrusion may be the options before the restoration. ${ }^{1-4}$

Developments in the aesthetic properties of restorative materials allow the clinicians to perform perfect restorations without any extra tooth structure loss. ${ }^{4}$ However, in the tooth structure, dental tissue loss may occurred due to various reason such as trauma and dental caries. Post-core treatment may be required in teeth with dental tissue loss for retention and resistance. . $^{5-7}$

Restoration of the fractured teeth with lost structures is a complicated situation for the clinicians. Reattachment of the fractured tooth parts is the optimum treatment option in order to obtain perfect aesthetic and function. ${ }^{4}$ Reattachment treatment provides natural appearance in a short chair-time. ${ }^{8}$ Resin-based restorative materials are often used in reattachment method. In order to enhance the weak mechanical properties, fiber post materials have been developed. These post types have advantages such as aesthetic, adhesion to the tooth structure, Young's modulus similar to dentine. However, these post types still need dentin preparation while fitting into the root canal. ${ }^{4}$

Optimal post system must increase the retention of core without causing stress accumulation on remaining tooth structure. ${ }^{9}$ Present studies have showed that fiber reinforced composite posts resist against the stress accumulation even if placed to the half of the canal. ${ }^{5}$

Ideal post and core materials must be similar to the dentine in terms of Young's modulus, compression strength, thermal expansion coefficient. ${ }^{10}$

Carbon and glass fiber posts have similar Young's modulus to dentine. This situation prevents stress accumulation between the dentin and post interface. Therefore, dentine-post separation is a rare situation for carbon fiber posts (CFP). Also, CFP absorbs some of the stress accumulation that occurs on the restoration. CFP have been designed in such a way that distribute the compressive and shear stresses to the tissues. ${ }^{11,12}$

Glass fiber post (GFP) is aesthetic, and can be used with composite and full ceramic restorations. GFP has high bonding durability with resin cements. ${ }^{12,13}$ GFP has similar flexural strength with dentine and distribute the stresses to the large surfaces. Colorless and tissue compatibility are the other advantages of GFP. ${ }^{14-16}$

Finite element analysis method (FEM) has a high acceptance in terms of modeling the teeth's and periodontium's biophysical properties on computer. FEM is ultra-helpful methods that stimulate the effect of chewing forces on restorative material and dental hard tissue. FEM shows the geometry of the structure, loadings and limitations based to mathematics. Deformations and stresses can be evaluated in any side of the model. The Young's modulus and Poisson ratio are specific for each element. ${ }^{17}$

The aim of this study is to evaluate by FEM the stress distribution and localization under simulated biting forces of computerized teeth models with complicated crown-root fracture which reattachment by 2 different post systems.

\section{MATERIALS AND METHODS}

This silico study was planned in Dicle University Faculty of Dentistry Department of Pediatric Dentistry. FEM was practiced in Dicle University Faculty of 
Engineering Department of Mechanical Engineering. Stress analysis was performed on maxillary central teeth with two different post systems (Group I and II), using stress analysis software (ANSYSRel.6.0, ANSYS Inc., Houston, TX, USA). Glass fiber post was reattachment fractured tooth fragment in group I. In group II, carbon fiber post system was used $(10 \mathrm{~mm}$ insertion depth, about $2 / 3$ of the root). Teeth were modeled in 10 layers as; gingiva, cortical bone, sponges bone, periodontal ligament, gutta-percha, enamel, post system, composite resin core and cement (Figure 1 and 2). The dentin wall thickness was designed as $2.5 \mathrm{~mm}$. The alveolar bone was placed apically $2 \mathrm{~mm}$ from the cement-enamel junction. The periodontal ligament was simulated as a ring with a thickness of $0.2 \mathrm{~mm}$ around the tooth model and a cortical bone with a thickness of $0.5 \mathrm{~mm}$. Post systems were practiced to the teeth and $100 \mathrm{~N}$ force loaded to the incisal edge of the teeth with $90^{\circ}$ angle (Vertical direction) for imitate the bite force. 100 $\mathrm{N}$ forces was expanded to all part of the teeth ${ }^{18,19}$ (Figure 3).

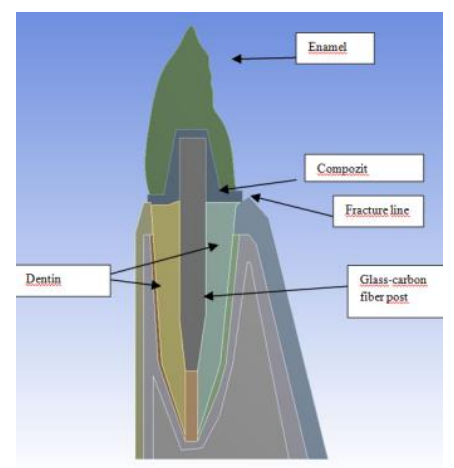

Figure 1. Working model

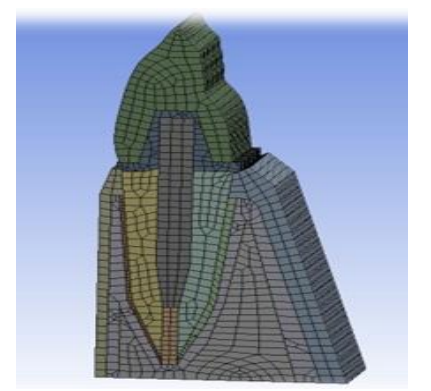

Figure 2. Mesh model

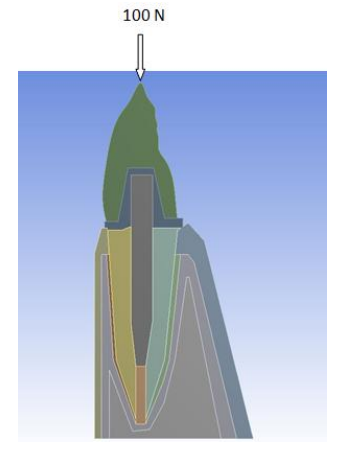

Figure 3. $100 \mathrm{~N}$ force loaded to the incisal edge of the teeth with $90^{\circ}$ angle.

The strains at gingiva, cortical bone, spongios bone, periodontal ligament, dentine, gutta-percha, enamel, post system, composite resin core and cement were calculated and the calculations were taken as equivalent von-Mises strains (Table 1). Intel Pentium $®$ D CPU 3,00 GHz drawer, 250gb Hard disc, 3.00 GB RAM equipped and Windows XP Professional Version 2002 Service Pack 3 computer, Nextengine (NextEngine, Inc. 401 Wilshire Blvd., Ninth Flor Santa Monica, California 90401) and Rhinoceros 4.0 (3670 Woodland Park Ave N,Seattle, WA 98103 USA) were used for modeling.

Table 1. The Young's modulus and Poisson ratio of the materials of the study. ${ }^{19}$

\begin{tabular}{|l|l|l|}
\hline Material & $\begin{array}{l}\text { Young's } \\
\text { modulus(GPa) }\end{array}$ & $\begin{array}{l}\text { Poisson } \\
\text { ratio }\end{array}$ \\
\hline Dentine & 18.6 & 0.31 \\
\hline Enamel & 41.0 & 0.30 \\
\hline Periodontal ligament & $68.9 \times 10^{-3}$ & 0.45 \\
\hline Cortical bone & 13.7 & 0.30 \\
\hline Spongios bone & 1.37 & 0.30 \\
\hline Gingiva & $19.6 \times 10^{-3}$ & 0.30 \\
\hline Gutta-percha & $0.69 \times 10^{-3}$ & 0.45 \\
\hline Glass fiber post & 40 & 0.18 \\
\hline Carbon fiber post & 125 & 0.2 \\
\hline
\end{tabular}

\section{RESULTS}

$100 \mathrm{~N}$ forces were loaded from the incisal edge with $90^{\circ}$ angles to the tooth models with glass fiber and carbon fiber post systems. Following the loading, the durability of the tooth with glass fiber post system against the force was found more than the tooth with carbon fiber post system. The stress concentration was found at the palatinal surfaces (in chole) of either model. As the results of analysis, the resistance of

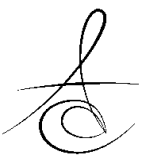


glass fiber post against the forces was higher than the carbon fiber post. (Table 2, Figure 4 and 5). As reported in Fig. 4-5, in the case of a vertical $100 \mathrm{~N}$ force, the values of the Von Mises stresses (MPa) are distributed mainly crown and root.

Table 2. The maximum and minimum duration of 2 different post systems against the $100 \mathrm{~N}$ forces.

\begin{tabular}{|l|l|l|}
\hline \multicolumn{2}{|c|}{ Post Systems } & \multicolumn{1}{|c|}{${\text { Maximum } \mathrm{e}^{7}}$ Minimum $^{5}$} \\
\hline $\begin{array}{l}\text { Glass fiber } \\
\text { post system }\end{array}$ & 7,0225 & 5,1049 \\
\hline $\begin{array}{l}\text { Carbon fiber } \\
\text { post system }\end{array}$ & 6,9851 & 5,1107 \\
\hline
\end{tabular}

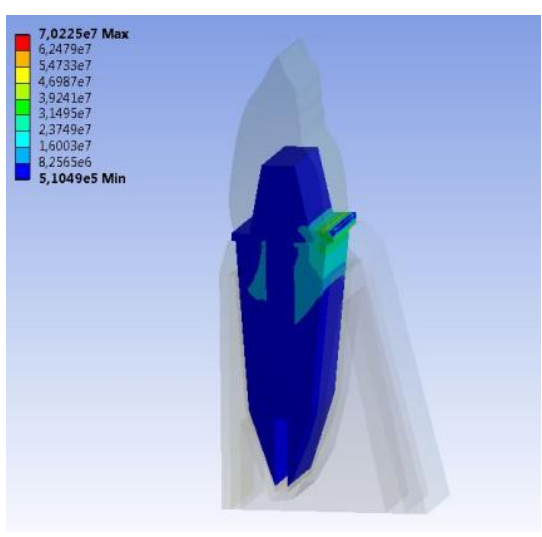

Figure 4. The maximum and minimum duration of glass fiber post against the $100 \mathrm{~N}$ forces

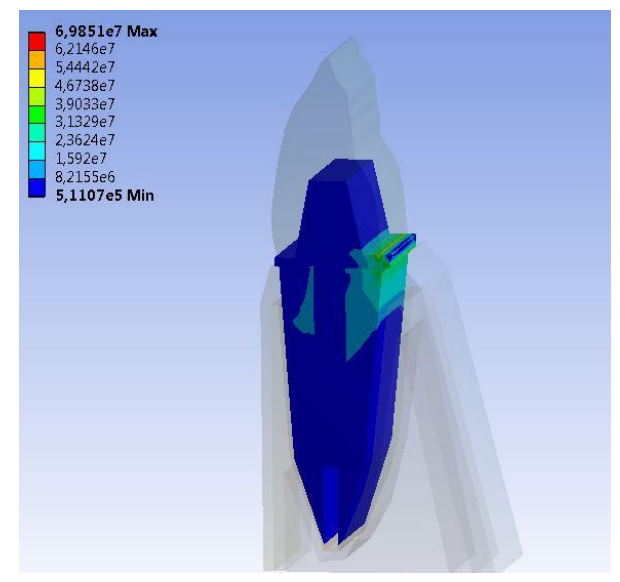

Figure 5. The maximum and minimum duration of carbon fiber post against the $100 \mathrm{~N}$ forces.

\section{DISCUSSION}

Reattachment technique is first choice for crown fractures of anterior teeth because of influences to esthetic by retaining natural translucency and surface texture. In crown and crown-root fracture, the esthetic rehabilitation can be obtained in a single appointment. Also, this procedure is relatively simple, atraumatic and inexpensive. ${ }^{4}$ Complicated crown-root fractured teeth, after endodontic treatment, can be reconnected using a post and a bonded adhesive to the fractured fragments and composite resin. Satisfactory aesthetic and functional results can be obtained in this a short time. ${ }^{20}$

The elastic modulus of the posts to be used in the restoration should have a similar to that elastic modulus of the dental tissues. The modulus of elasticity of the carbon and glass fiber post (about 18$20 \mathrm{GPa}$ ) is similar to the elastic modulus of the dentin. The elastic modulus of cast metal alloys and prefabricated metal post is about $150-200 \mathrm{GPa}$. These posts can cause of fractures of restoration and root. Biological restoration in a young patient with a complicated crown root fracture with an autogenous tooth fragment. ${ }^{21,22}$ For all these reasons, carbon fiber and glass fiber posts have been decided to use in our study.

Various methodologies have been used in order to examine the stress concentration and measurement. These include working models with articulation, photo-elastic method, strength measurement method and finite element analysis. ${ }^{23}$ The advantages of FEM are multiplexed and important. Even if the structure which will be analyzed is not homogeneous an accurate stress template can be achieved. After a detailed computer supported design model was developed, FEM decreases the needed prototype number and helps for saving time and money. ${ }^{24}$ In our study, the advantages and superiorities of FEM were used to evaluate the distribution of post materials on computer.

Pereira et al. have examined the characteristic durations of 4 post types that include glass fiber and carbon fiber posts and have found the characteristic duration of carbon fiber posts is higher than other post types. ${ }^{25}$ Kumar et al. reported that stresses accumulate in the apical region of the metal posts and in the cervical region of the fiber posts. They also

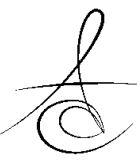


Atatürk Üniv. Diş Hek. Fak. Derg.

J Dent Fac Atatürk Uni

Cilt:28, Sayı:3, Yıl: 2018, Sayfa, 326-332
KARAALİ, DOĞAN, GÜNAY indicated that stress in the dental structure would decrease with increasing fiber post diameter. ${ }^{23}$ In our study, it was found that the stress accumulation occurred in the cervical region of both post types, and that glass fiber posts are more resistant to stress.

Karre et al. reported that reattachment using fiber post has the highest fracture resistance, in vitro study about reattachment method and fiber post. ${ }^{26}$ Akkayan et al. have examined titanium, zirconium, glass fiber and quartz fiber posts on 40 extracted upper canine incisors in terms of fracture resistance with universal test machine and quartz fiber post systems have showed the highest fracture resistance. Glass fiber and zirconia post systems have found statistically similar. ${ }^{27}$ In our study with finite element method, the maximum and minimum resistance values of glass fiber post systems were found higher than carbon fiber post systems.

Qing et al., in study about fracture resistance of glass fiber and cast post systems in root-canal treated teeth, reported lower fracture of resistance glass fiber posts than cast posts. ${ }^{28}$ In our study, we aimed to examine the maxillary central teeth which are most important to the aesthetic and which are exposed to most crown fractures. Cast and prefabricate metal posts were not included to the study due to aesthetical problems.

Sorrentino et al., in study about glass fiber post, reported that when the tooth applies $10 \mathrm{~N}$ forces to the long axis, the least strain is accumulated in the root apex and the most strain is accumulated on the buccal surface of the root. However, stress accumulation occurred at the boundary of the enamelcemento junction. ${ }^{29}$ Hayashi et al. reported in the study that the fractures have occurred in cervical regions under the $90 \mathrm{~N}$ vertical loads and in the middle or apical parts of the teeth under the $45 \mathrm{~N}$ oblique loads in two-thirds of all fractured teeth. ${ }^{30}$ Rodriques et al. reported that FEM was validated with in vivo strain values measured at the buccal crown surfaces, under $155 \mathrm{~N}$ force from contact of antagonist teeth. ${ }^{31}$ In our study, under the $90^{\circ}$ vertical $100 \mathrm{~N}$ forces, in both post types the stress accumulated in cervical region.

Pegoretti et al. reported that the glass fiber composite exhibited the lowest stresses in the root, as its hardness was very similar to dentin when compared to the cast metal and carbon fiber post. ${ }^{19}$
Silva et al. reported that fiber posts show a more homogeneous stress distribution than titanium and metallic posts. ${ }^{32}$ Deger et al. reported that glass fiber posts $100 \mathrm{~N}$ is more resistant than metallic posts under vertical occlusal force. ${ }^{33}$ However, Chen et al. reported that CAD/CAM glass fiber post is produce to stress in dentin, and is least recommended because of stress level. ${ }^{34}$ As a result of this study, glass and carbon fiber post were showed homogeneous stress distribution. However, the values of the Von Mises stresses of glass fiber post were found higher than carbon fiber post.

\section{CONCLUSION}

Complicated crown-root fractures may occur in anterior group teeth as a result of trauma in children. There are esthetic and functions problem in patient. The esthetic and function can recycled by used post system and fractured tooth fragment. We used two different post types in teeth with complicated crownroot fractures. In conclusion, it was determined that, under the functional forces, duration of the teeth with glass fiber post was higher than the duration of the teeth with carbon fiber post and the stress accumulation was observed mostly at palatal regions of the teeth. However, in a real patient, the response given by the stresses is more complex. Additionally, the fractured tooth model which used in our study is a rare occurs in real life. The FEM used in this study is a necessary step in the transition to later laboratory tests. In addition, clinical investigations are needed for the success and long-term use of post systems.

\section{Conflicts of interest}

The authors have no conflicts of interest relevant to this article.

\section{Acknowledgements}

The authors would like to thank DrEmre Ari (Dicle University, Faculty of Engineering, Department of Mechanical Engineering) for his helpful advice on the finite element analysis

Abdullah Emre Karaali: ORCID ID: 0000-0002-6286-5347 Mehmet Sinan Doğan: ORCID ID: 0000-0002-3089-1305 Ayşe Günay: ORCID ID: 0000-0002-0918-7962

\section{REFERENCES}

1. Brown GJ, Welbury RR. Case report: Root extrusion, a practical solution in complicated crown-root incisor fractures. $\mathrm{Br}$ Dent J.2000;9:477-8. 
2. Pavone AF, Ghassemian M, Mancini M, Condò R, Cerroni L, Arcuri C, Pasquantonio G. Autogenous Tooth Fragment Adhesive Reattachment for a Complicated Crown Root Fracture: Two Interdisciplinary Case Reports. Case Rep Dent. 2016;2016:9352129.

3. Bajaj P, Chordiya R, Rudagi K, Patil N. Multidisciplinary approach to the management of complicated crown-root fracture: a case report. J Int Oral Health. 2015;4:88-91

4. Adanir N, Ok E, Erdek Y. Re-attachment of subgingivally oblique fractured central incisor using a fiber post. Eur.J.Dent, 2008; 2:138-41.

5. Jang JH, Park SJ, Min KS, Lee BN, Chang HS, Oh $W M$, et al. Stress behavior of cemented fiberreinforced composite and titanium posts in the upper central incisor according to the post length: Two-dimensional finite element analysis. J Dent Sci, 2012;4:384-9.

6. Vafaei A, Ranjkesh B, Lovschall H, Erfanparast L, Jafarabadi MA, Oskouei SG, Isidor F. Survival of Composite Resin Restorations of severely Decayed Primary Anterior Teeth retained by Glass Fiber Posts or Reversed-orientated Metal Posts. Int J Clin Pediatr Dent. 2016;2:109-13.

7. Cheung W. A review of the management of endodontically treated teeth. Post, core and the final restoration. JADA. 2005;5:611-9.

8. Tuğut $F$, Demir $H$, Doğan $O M$. Restoration of a fractured anterior tooth supported with prefabric post and original tooth fragment: A case report. Anat J Clin. Invest, 2011;3;144-8.

9. Alharbi F, Nathanson D, Morgano SM, Baba NZ. Fracture resistance and failure mode of fatigued endodontically treated teeth restored with fiber-reinforced resin posts and metallic posts in vitro. Dent Traumatology, 2014;4:317-25.

10. Kurthukoti AJ, Paul J, Gandhi K, Rao DB. Fracture resistance of endodontically treated permanent anterior teeth restored with three different esthetic post systems: An in vitro study. J Indian Soc Pedod Prev Dent 2015;33:296-301.

11. Teixeira CS, Pasternak-Junior B, Borges $A H$, Paulino SM, Sousa-Neto MD. Influence of endodontic sealers on the bond strength of carbon fiber posts. J Biomed Mater Res B Appl Biomater. 2008;2:430-5.
12. Vichi A, Grandini S, Ferrari M. Clinical procedure for luting glass-fiber posts. J Adhes. Dent 2001; 3: $353-9$.

13. Schmage $P$, Pfeiffer $P$, Pinto $E$, Platzer $U$, Nergiz I. Influence of oversized dowel space preparation on the bond strengths of FRC posts. Op. dentistry 2009;1:93-101.

14. Ferrari M, Vichi A, Grandini S, Goracci C. Efficacy of a self-curing adhesive resin cement system on luting glass-fiber posts into root canals: an SEM investigation. Int J Prosthodont 2001;14: 543-9.

15. Goracci C, Corciolani G, Vichi A, Ferrari M. Light transmitting ability of marketed fiber posts. J Dent. Rest. 2008;87:1122-6.

16. Mallmann A, Jacques LB, Valandro LF, Muench A. Microtensile bond strength of photoactivated and autopolymerized adhesive systems to root dentin using translucent and opaque fiber-reinforced composite posts. J Prosthet Dent 2007;97:165-72.

17. Guven S, Akdogan M, Oz C, Dogan MS, Unal M, Unal S, Sahbaz C. Three-dimensional finiteelement analysis of two ceramic inlay restorations with different cavity designs, Biotechnology \& Biotechnological Equipment, 2015;3:579-585.

18. Bulut AC, Atsü SS. Diş hekimliğinde restoratif materyallerin yaşlandırma işlemleri ve çiğneme simülatörleri. J Dent Fac Atatürk Uni 2016;26: 180-6.

19. Pegoretti A, Fambri L, Zappini G, Bianchetti M. Finite element analysis of a glass fibre reinforced composite endodontic post. Biomaterials. 2002;23:2667-82.

20. Kulkarni VK, Sridhar R, Duddu MK, Banda NR, Sharma DS. Biological restoration in a young patient with a complicated crown root fracture with an autogenous tooth fragment. J Clin Pediatr Dent. 2013;2:117-21.

21. Kulkarni VK, Sridhar R, Duddu MK, Banda NR, Sharma DS.J Clin Pediatr Dent. 2013;38:117-21.

22. Lamichhane A, Xu C, Zhang FQ. Dental fiber-post resin base material: a review.J Adv Prosthodont. 2014;1:60-5.

23. Kumar $P$, Rao RN. Three-dimensional finite element analysis of stress distribution in a tooth restored with metal and fiber posts of varying diameters: An in-vitro study. J Conserv Dent. 2015;2:100-4

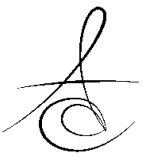


24. Geramy A, Sharofoddin F. Abfraction: 3D analysis by means of the finite element method. Quint. Int. 2003;7:526-33.

25. Pereira JR, do Valle AL, Shiratori FK, Ghizoni JS, Bonfante EA. The effect of post material on the characteristic strength of fatigued endodontically treated teeth. J Prosthetic dent. 2014; 112:122530.

26. Karre D, Muppa R, Duddu MK, Nallachakrava S. Fracture resistance of reattached fragments using three different techniques with emphasis on vertical grooves and fiber-reinforced composite post: A novel technique. J Conserv Dent. 2017; 20:474-8.

27. Akkayan B, Gülmez T. Resistance to fracture of endodontically treated teeth restored with different post systems. Jprosthetic dent. 2002; 87:431-7.

28. Qing $H$, Zhu Z, Chao $Y$, Zhang W. In vitro evaluation of the fracture resistance of anterior endodontically treated teeth restored with glass fiber and zircon posts. J Prosthetic Dent. 2007;2:93-8.

29. Sorrentino $R$, Aversa $R$, Ferro $V$, Auriemma $T$, Zarone $F$, Ferrari $M$, Apicella A. Three-dimensional finite element analysis of strain and stress distributions in endodontically treated maxillary central incisors restored with different post, core and crown materials. Dent Mater. 2007; 23:98393.

30. Hayashi M, Takahashi Y, Imazato S, Ebisu S. Fracture resistance of pulpless teeth restored with post-cores and crowns. Dent Materials 2006;5:477-85.

31. Rodrigues MP, Soares PBF, Valdivia ADCM, Pessoa RS, Veríssimo C, Versluis A, Soares CJ. Patientspecific Finite Element Analysis of Fiber Post and Ferrule Design. J Endod. 2017;9:1539-44.

32. Silva NR, Castro CG, Santos-Filho PC, Silva GR, Campos RE, Soares PV, Soares CJ. Influence of different post design and composition on stress distribution in maxillary central incisor: Finite element analysis. Indian J Dent Res 2009;20:1538.
33. Değer $Y$, Adigüzel Ö, Yiğit Özer $S$, Kaya $S$, Seyfioğlu Polat $Z$, Bozyel B. Evaluation of Temperature and Stress Distribution on 2 Different Post Systems Using 3-Dimensional Finite Element Analysis. Med Sci Monit. 2015; 29:371621

34. Chen A, Feng X, Zhang $Y$, Liu R, Shao L. Finite element analysis of stress distribution in four different endodontic post systems in a model canine. Biomed Mater Eng. 2015; 26: 629-35.

\section{Yazışma Adresi}

Mehmet Sinan DOĞAN

Harran University, Faculty of Dentistry, Department of Pediatric Dentistry 63300 ŞANLIURFA / TURKEY

E-mail: dtlider@hotmail.com

Runing Title: Crown-Root Fractures and Finite Element Analysis 